\title{
Much Bigger Than a Hamburger: Disrupting Problematic Picturebook Depictions of the Civil Rights Movement
}

\author{
Noreen Naseem Rodríguez \\ lowa State University \\ U. S. A. \\ Amanda E. Vickery \\ University of North Texas \\ U. S. A.
}

ABSTRACT: While more diverse children's literature about youth activism is available than ever before, popular picturebooks often perpetuate problematic tropes about the Civil Rights Movement. In this article, we conduct a critical content analysis of the award-winning picturebook The Youngest Marcher and contrast the book's content to a critical race counterstory of the Movement focused on the collective struggle for justice in the face of racial violence. We argue for the need to engage students in critical race media literacy and offer ways to nuance the limited narratives often found in children's literature.

KEYWORDS: Children's literature, Civil Rights Movement, counterstory, critical race media literacy

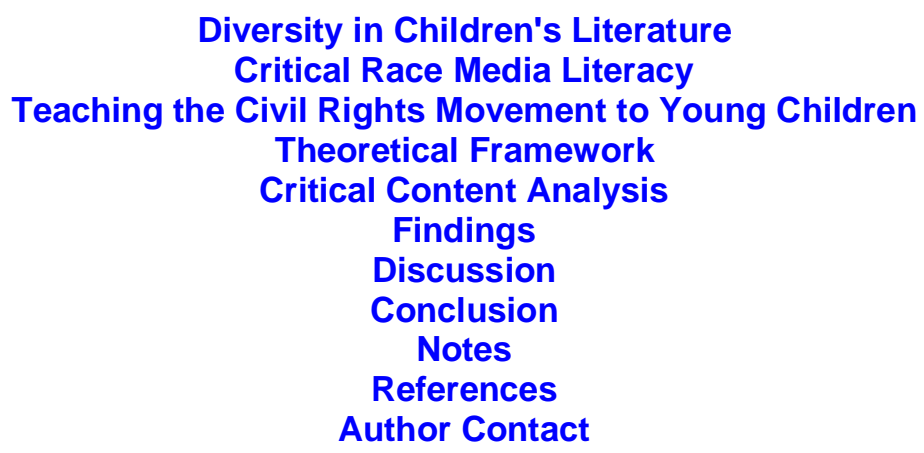

When the 1960s sit-in movement erupted in the United States, civil rights activist Ella Baker immediately saw the potential of young people and the contributions they could make to the Civil Rights Movement (CRM). Baker, a skilled activist with decades of organizing experience, organized a Student Leadership Conference that brought together young people from across the country to meet and share civil disobedience tactics. Sixty years after that germinal gathering of young activists, the teaching of the CRM to young children is typically relegated to Rosa Parks and Martin Luther King, Jr. (Busey \& Walker, 2017), omitting aspects such as youth activism in elementary classrooms. Recently, several picturebooks 
centering the role of youth and young adults in the CRM have been published. This paper uses critical race media literacy alongside critical race counterstory to interrogate the representations of the CRM in an award-winning picturebook about a young civil rights activist, examining how the book perpetuates individualist popular media tropes about the CRM rather than providing an accurate portrayal of collective resistance.

\section{Diversity in Children's Literature}

Due to their pervasive use in elementary classrooms, picturebooks may offer perspectives absent in traditional textbooks (Morgan, 2009). Picturebooks merge the verbal and the visual, with equal importance given to both aspects, hence the use of a single word to describe them (Sipe, 2001). However, as children's literature is linked to the social, political, and economic ideologies present in society (Botelho \& Rudman, 2009), many picturebooks lack historical accuracy and can perpetuate, rather than disrupt and dismantle, stereotypes about marginalized groups (Rodríguez \& Kim, 2018).

Like all media, American children's literature shifts over time, reflecting changes in broader society. In 2014, renowned children's authors Walter Dean Myers and Christopher Myers published New York Times op-eds calling for greater attention to the lack of racial and ethnic diversity in children's literature (C. Myers, 2014; W. D. Myers, 2014). A month later, authors Ellen Oh, Malinda Lo, and Aisha Saeed established a social media campaign entitled \#WeNeedDiverseBooks to galvanize support for the increased publication and promotion of diverse youth literature. While statistics from the Cooperative Children's Book Center (2019) demonstrate an increase in books written about Communities of Color, questions regarding how these communities are depicted remain (Rodríguez \& Kim, 2018; Dahlen, 2019; Thomas, Reese, \& Horning, 2016).

Zapata et al. (2018) suggest the use of a race-conscious lens in the selection of picturebooks. For example, the authors note the importance of examining historical accuracy, the authenticity of portrayals, and consideration for voices and perspectives that might be missing. While their work specifically examined picturebooks depicting slavery, their approach reflects broader social conversations and scholarship around the importance of books written through what author Corinne Duyvis termed \#OwnVoices (Yorio, 2018), or authors who share the same identities as the marginalized characters about whom they write (Woodson, 2003). Yet despite social media movements like \#WeNeedDiverseBooks and \#OwnVoices in response to decades of stereotypical and inauthentic portrayals in children's literature, historically marginalized groups continue to be under- and misrepresented in children's literature, and the sheer presence of so-called "diverse" texts in a classroom does not guarantee that such books will be read and/or taught in ways that uplift marginalized groups and does not guarantee the teaching of our truths and hard histories. 


\section{Critical Race Media Literacy}

Young students' developing understanding of the world around them includes representations both within and beyond the classroom walls. While scholars have long debated whether media or schools are more influential pedagogues (Buckingham, 2003; Pierce, 1970), researchers have increasingly recognized that "education must meet the dual challenges of teaching media literacy in a multicultural society and sensitising students and the public to the inequities and injustices of a society based on gender, race, and class inequalities and discrimination" (Kellner \& Share, 2005, p. 370). Critical media literacy involves the cultivation of skills that address both challenges (Kellner \& Share, 2005).

In the field of elementary social studies education, examples of youth civic agency are frequently bereft of attention to racial identity and difference (Brugar, 2015; Mitra \& Serriere, 2015). Specifically, social studies research largely neglects to consider how the racial identity of both teachers and students differently impacts how youth agency may be (un)welcomed and (un)supported (Falkner, 2020; Ramirez \& Jaffee, 2016; Rodríguez, 2018; Rodríguez \& Salinas, 2019; Salinas \& Castro, 2010; Vickery, 2016, 2017). As both media and schools create, maintain, and justify racism (Ladson-Billings \& Tate, 1995; Love, 2019; Yosso, 2002a, $2002 b)$, critical race media literacy demands the confrontation of troubling or problematic racial representations, an interrogation of the positionality of media producers and the purposes and consequences of media, and agentic, actionoriented challenges to problematic narratives (Hawkman \& Shear, 2017; Hawkman \& Van Horn, 2019).

Complicating the implementation of critical race media literacy with young children is the racial divide between how teachers and parents perceive the need to protect or preserve the innocence of young children. In particular, white 1 teachers often insist on shielding children from classroom conversations centered on violence and racism (Bolgatz, 2007), deeming such topics as inappropriate or beyond the comprehension of young children; similarly, white parents are far less likely to discuss issues of race and ethnicity than Black, Latinx, and Asian American parents (Epstein, 2010; Kotler, Haider, \& Levine, 2019). Such perceptions deny the unequal impact of racial violence, both verbal and physical, on Communities of Color, for as white teachers protect students from these topics, such discussions often take place with great deliberation in the homes of families of Color.

As Communities of Color witness a barrage of anti-Black and Brown violence, from disproportionate school discipline to the murder of Black and Brown children and adults in streets and automobiles, on playgrounds, in places of worship, and even in their own homes, family conversations about the incessant potential of violence that may be inflicted upon them occur out of necessity (Gay, 2015; Packnett, 2019; Smith, 2019). As Love (2019) argues, "Being a person of color is a civic project because your relationship to America, sadly, is a fight in order to matter, to survive, and one day thrive" (p. 8). In a world where increasingly tech-savvy youth are influenced by media outside of family and school, critical race media literacy development must intentionally take place in classrooms in ways 
that recognize that "the categories of child, youth, or adult and their accompanying legal, political, and social conditions are never produced in isolation from race, sexuality, gender, ability, geography, and socioeconomics" (Meiners, 2015, p. 124).

\section{Teaching the Civil Rights Movement to Young Children}

The CRM is one of the few U.S. historical events centered on race that is commonly taught in elementary classrooms. Overwhelmingly, children's literature and lessons about the CRM emphasize nonviolence with narratives centered around a 'tired' Parks who launched a bus boycott in Montgomery (Kohl, 1991) and brave King's dream proclaimed at the March on Washington (Busey \& Walker, 2017; Wills, 2005). Of less import in these narratives is collective organizing and solidarity (e.g., Highlander Folk School). In the popular teaching of the CRM, certain aspects of the struggle are commonly overlooked, namely the dehumanization and degradation of Black people that continued long after the end of enslavement (Brown \& Brown, 2010), "white rage" (Anderson, 2016), racism and segregation that existed in the North, or the unpopularity of the movement among white Americans in the 1950s and 1960s2 (Theoharis, 2018). Moreover, students fail to learn of the role the Federal Bureau of Investigation played in targeting, infiltrating, discrediting and surveilling Black leaders and organizations (e.g., COINTELPRO). This fundamental knowledge would demonstrate to students the ways in which inequality has been perpetrated, experienced, and maintained. Unfortunately, "these uncomfortable truths find little place in our public celebrations of the civil rights movement" (Theoharis, 2018, p. 182).

Instead, educators often teach the CRM through sanitized narratives of youth activism, from the story of Ruby Bridges 3 to the Little Rock Nine and the college students who initiated the Greensboro sit-ins (Ciardiello, 2004; FerrerasStone \& Demoiny, 2019; Lindquist, 2019). Traditional approaches to teaching the CRM often end with an emphasis on student voice and agency while presenting racism as resolved in American society. Yet for students from historically and contemporarily marginalized communities, "'conventional' civic engagement like voting or writing letters to representatives have been lessons in futility or have excluded them from participation" (Swalwell \& Payne, 2019, p. 129). Furthermore, CRM children's literature is often praised with little critique or consideration for racially distinct audiences (Brugar, 2015, 2018; Ferreras-Stone \& Demoiny, 2019; Libresco, 2018), rarely attending to how the reader, text, and society are positioned (Botelho \& Rudman, 2009); the ways in which such narratives uphold whiteness (Gates, Ricks, \& Rodríguez-Astacio, 2020); and how narratives reify problematic tropes of racism as resolved and America as a country of constant racial progress (Wills, 2001).

In teaching the CRM, educators should consider how students' various identities "provide differing histories, politics, and ideas about how to engage civically" (Swalwell \& Payne, 2019, p. 129) and should avoid presenting any type of civic engagement as natural, apolitical, or preferable. Moreover, educators 
should more deeply interrogate author positionality and perspective when selecting books for classroom use. In this study, we explore how the teaching of the CRM in elementary classrooms might achieve greater racial realism 4 by allowing students to understand racial progress as an ongoing project involving constant steps forward and backward at multiple levels and with a wide range of actors.

\section{Theoretical Framework}

In order to more intentionally attend to the role of narratives in the teaching of the CRM to young learners, we adopt a critical race framework in this study of children's literature. Critical race theory views racism as a normal part of U.S. society and stresses the importance of experiential knowledge expressed through storytelling. "Majoritarian" stories are generated from a legacy of racial privilege, in which racial subordination is perceived as natural, and white middle/upper class cisheteronormativity is the norm (Solórzano \& Yosso, 2002). Majoritarian stories are so-named because they are pervasive and considered common knowledge. In contrast, critical race storytelling allows racially subordinated persons to make clear their lived conditions, challenge majoritarian tales, open new windows into reality, and engage conscience (Bell, 1987, 1992; Delgado, 1989; Solórzano \& Yosso, 2002). As the stories of Communities of Color often disrupt and subvert prevailing mindsets related to the presence and effects of racism in the United States, counterstories describe narratives told by those who have been oppressed, victimized, and brutalized by the mechanisms of white supremacy (Delgado, 1989).

Our utilization of counterstory as a theoretical frame draws inspiration from civil rights organizer Ella Baker, who urged, "In order to see where we are going, we not only must remember where we've been, but we must understand where we have been" 5 . A study of the CRM must necessarily begin long before the 1960s6; however, majoritarian tales in the form of children's literature are largely unwilling to make this leap into the nation's sordid past. Instead, the "stock story" (Delgado, 1989) of the CRM is reduced to the desire for simplistic interpretations of equality borne out of frustration and inconvenience, such as Black and white children longing to be side-by-side in private and public establishments. Yet, in describing youth-led activism such as lunch counter sit-ins and other demonstrations, Baker (1960) was adamant that youth were

concerned with something much bigger than a hamburger or even a giantsized Coke. Whatever may be the difference in approach to their goal, the Negro and white students, North and South, are seeking to rid America of the scourge of racial segregation and discrimination-not only at lunch counters, but in every aspect of life. (n.p.)

A counterstory of the CRM would explicitly describe the ongoing dehumanization experienced by Black Americans in the twentieth century and today in every aspect of life; such a counterstory would recognize the trauma and terror this dehumanization incurred and continues to incur upon Black bodies, regardless of 
age, and would make clear that desegregation was necessary as part of the unalienable rights and democratic ideals of "life, liberty, and the pursuit of happiness" promised-yet unfulfilled-by the Declaration of Independence. This particular stock story and counterstory are centered in our use of critical race theory to understand the verbal and visual representations found in a popular CRM picturebook.

\section{Critical Content Analysis}

This paper describes a critical content analysis of an award-winning picturebook, The Youngest Marcher (2017) by Cynthia Levinson. Short (2017) describes critical content analysis as a research methodology that brings a critical lens to text analysis to explore underlying messages, particularly as related to power. Critical content analysis begins with a tension and an initial set of research questions that are transformed through interactions with the data (Short, 2017). As women social studies scholars of Color and former classroom teachers who specialize in the teaching of Black and Brown histories to young children, we have long been drawn to children's literature about Communities of Color and routinely explore and discuss new picturebooks about these topics. However, we are often troubled by the historical narratives presented in the texts. While we recognize the delicate nature of describing traumatic histories to young learners, we firmly believe that children need opportunities to wrestle with the injustices of our past to inform their understanding of the present (e.g., Kent, 1999; Rodríguez, 2018; Rodríguez \& Kim, 2018; Zapata et al., 2018). Short (2017) considers personal response to text to be the first step of a critical content analysis: immersion as a reader, rather than as a researcher, with the identified texts. After our initial readings in which we encountered multiple moments of dissonance between the book's narrative and historical fact, we determined that critical race theory, and counterstories specifically, was the most effective lens to analyze the text.

The Youngest Marcher (Levinson, 2017) received, among other honors, the 2018 Carter G. Woodson award from the National Council for the Social Studies; this award is given annually to nonfiction books written in the United States with a focus on ethnic/racial minority groups (Brugar, 2018). The book highlights youth action during the CRM with a focus on Black elementary student Audrey Faye Hendricks and has been highly recommended as an exemplary tale of youth activism (Ferreras-Stone \& Demoiny, 2019; Libresco, 2018). Our critical content analysis took into account both written and visual text, considered equally important in picturebooks (Sipe, 2001). Additionally, we drew from Solórzano and Yosso (2002) to construct a counterstory to the book's narrative comprised of (a) data gathered from the picturebook analysis, (b) the existing literature on the CRM, (c) our professional experiences as educators and scholars of Color, and (d) our personal experiences as women of Color. An important aspect of critical race methodology is the centering of students of Color in analysis (Solórzano \& Yosso, 2002); this impacted our analysis of the book and the counterstory constructed in response. We read the book independently, recording first cycle codes and memos related to the presentation of race in the historical narrative and illustrations. Then 
we shared individual findings and developed second cycle codes about audience and racial violence, from which we determined patterns and themes leading to the findings that follow.

\section{Findings}

\section{Much Bigger Than a Hamburger}

The Youngest Marcher details young Audrey Faye Hendricks' participation in the 1963 Birmingham Children's Crusade7. While Audrey's age is never specified, she is described as "the youngest known marcher" (n.p.). The book begins by recounting King's occasional visits to the Hendricks home, where he and the other adults talked about "wiping out the segregation laws that kept black and white people apart in Birmingham" (Levinson, 2017, n.p.). In response, Audrey proclaims, "I don't want hand-me-down schoolbooks! But stools at the counter, plush movie theater seats, books so fresh they'd crackle when you open them-those were for white children" (Levinson, 2017, n.p.). The author portrays Audrey as a child only concerned about fighting segregation to gain access to the material aspects denied to Black Americans during Jim Crow.

From the onset of the book, the goals of the movement are misrepresented: African Americans were fighting for something greater than eating food at a restaurant counter or attaining "perks" reserved for whites (Baker, 1960). The conversations held by King and CRM leaders like Fred Shuttlesworth and Jim Bevel (all named in the book) likely centered demands for the dignity of living and existing as a full human being and citizen rather than simply ending laws that kept "black and white people apart" (Levinson, 2017, n.p.). Moreover, the laws responsible for segregation were created and enforced by white people; this fact is omitted entirely, and instead segregation is presented as an aspect of society that exists without perpetrators or supporters. The simplification of the Black freedom struggle narrative to the ability to share space and privileges with whites denies readers the opportunity to understand the violent and structural nature of oppression that results in the dehumanization of the oppressed and oppressor (Cesaire, 2000).

Instead, The Youngest Marcher promotes integration as the solution to the problem of segregation: the book ends with Audrey eating ice cream with her father next to white patrons. This image is paired with the text "Black and white together, like we belong" (Levinson, 2017, n.p.). The book upholds the narrative that allowing Black and white Americans to eat at the same restaurant was the goal of those who marched, and ultimately served as a solution to racism. Baldwins resists such simplistic accounts that presume white support for integration:

I don't know what most white people in this country feel," he said. "But I can only conclude what they feel from the state of their institutions. I don't know if white Christians hate Negroes or not, but I know we have a Christian church that is white and a Christian church that is black. I know, as Malcolm $\mathrm{X}$ once put it, the most segregated hour in American life is 
high noon on Sunday.... I don't know whether the real estate lobby has anything against black people, but I know the real estate lobby is keeping me in the ghetto. I don't know if the board of education hates black people, but I know the textbooks they give my children to read and the schools we have to go to. Now this is the evidence, you want me to make an act of faith, risking myself, my wife, my woman, my sister, my children on some idealism which you assure me exists in America, which I have never seen. (Peck, 2016)

While integrating public and private spaces was an important aspect of dismantling Jim Crow, the CRM also sought to disrupt structures and ideology that reinforced notions of white supremacy and Black inhumanity. Narratives like The Youngest Marcher aim to keep students ignorant of the past (Kent, 1999) by shielding (white) children from the harsh realities of white supremacy. Furthermore, such superficial narratives of the CRM are pervasive in the media and in schools, thus reinforcing the illusion that every historical narrative ends in a 'happy ending,' i.e., that we are currently living in a 'post racial' society.

\section{Avoidance of Racial Violence and Terror}

The gross simplification of the motivations behind the Movement is found throughout the text, but perhaps is most egregious when Audrey describes the testimonies heard at church. Levinson (2017) describes three "hateful stories," each accompanied by a vivid illustration by Vanessa Brantley Newton: "White store owners won't hire me" (emphasis in original); "Ku Kluxers chased me!"; and "Policemen called me names!" (n.p.). The first "hateful story" is reminiscent of many popular images of the CRM: a stern white man in a bow tie and apron waves away a Black man in a suit and tie beneath a "Whites only" sign. The second, however, is markedly rare in children's literature about the CRM.

The Ku Klux Klan (KKK) is widely recognized as a domestic terrorism organization (Anderson, 2016; Blight, 2002), and consequently rarely appears in CRM books for young readers. Levinson's (2017) mention of the Klan occurs alongside Brantley Newton's image of two hooded Klan members, one holding a torch while the other clutches a pitchfork, both looking menacingly at a Black man and two young children running away in fear. Yet the violence suggested by Brantley Newton's illustration is belied by Levinson's (2017) choice of phrasing: "Ku Kluxers chased me!" (n.p.) First, Levinson neglects to explain who "Ku Kluxers" are, why they might "chase" Black people, and why they are dressed in white robes and hoods. Her very use of the term "Ku Kluxers" versus more common references like "Klan members" seems oddly informal given the lack of explanation or prior reference. Second, her use of "chased" is innocuous, failing to explicitly attend to the threat of violence--and even death--that the KKK posed to Blacks and other marginalized groups.

In their extensive study on how social studies textbooks depict racial violence, Brown and Brown (2010) found that the only instances of racial violence represented in textbooks "ignore, undermine, or misrepresent the larger 
institutional/structural ties that supported (through actions and/or inactions) and, more important, benefited from, their enactment" (p. 45). Students are left to believe that individuals and/or groups (such as the police and the KKK) were the sole perpetrators of violence against African Americans and only when they stood up for their rights. The problem is that acts of violence portrayed in the media are disconnected from the institutions and structures that disenfranchised African Americans and reinforced the racial hierarchy. Moreover, by focusing on the spectacle of being 'chased' by the KKK, the individualized and collective everyday violence that Black Americans (both children and adults) experienced on a daily basis merely for existing is erased. If read without the support of an adult with both historical background knowledge and/or the courage to take up a difficult conversation about racial violence and domestic terrorism, children could easily read this sentence without understanding the gravity of the history behind it; moreover, the selection of the verb "chased" might be more reminiscent of playground pursuit, a far cry from brutality and violence that often resulted when members of the KKK pursued Black people in the 1960s and for decades prior.

Levinson's (2017) light-handed approach to the trauma and violence faced by Black Americans in the 1960s continues with the third account on the page. Below the words, "Policemen called me names!" (Levinson, 2017, n.p.), two police officers grasp their nightsticks menacingly as an older Black woman looks at them in fright, her arm raised defensively. While the illustration alludes to the threat of physical violence sensed by the Black woman, Levinson's words reduce the bodily threat to name-calling. While students might easily identify with the concept of name-calling, it is important to note the distinctions between schoolyard namecalling and racial slurs meant to diminish and dehumanize on the basis of skin color and notions of racial superiority. Moreover, police as well as members of white supremacist groups like the KKK did not hesitate to inflict harm on Black bodies. Levinson (2017), however, summarizes these three accounts as unfair "hateful stories" that made Audrey squirm, rather than as typical daily practices in a racist society that viewed and treated Black Americans as second-class citizens (Holt, 2010).

Levinson's (2017) reduction of racial violence and terror to these simplified statements is a mockery of the danger and violence Black children faced in the past and in present day. In particular, Black children during Jim Crow possessed a sophisticated and nuanced understanding of the reality and danger of living and existing as second-class citizens. When popular media white-washes the violent nature of white supremacy, students are robbed of an opportunity to learn about and celebrate the agency Black children exhibited when faced with the reality that, if they marched, protested, or demanded full personhood, they would be subjected to unspeakable violence. Black children knew the risks they faced, and nonetheless bravely participated in the CRM. If the purpose of social studies and teaching and learning about the past is to promote citizenship, students must cultivate a more critical understanding of citizenship that takes into account how Communities of Color understand, experience, and redefine citizenship (Rodríguez, 2018; Vickery, 2016, 2017). 


\section{Focus on Individual Action}

Frustrated by the "hateful stories" she has heard and inspired by Jim Bevel's idea for children to fill the jails of Birmingham, Alabama, Audrey joins the Children's Crusade with her parents' approval. The remainder of the book focuses on her experience from her arrival at the organizing site to her release after seven days spent in juvenile hall. Levinson (2017) recounts how Audrey "was the only protester from her school, the youngest child in the whole church, and she knew no one" (n.p.) and emphasizes the solitude Audrey felt due to her age. In the illustrations, Audrey appears alone and wide-eyed. On the page depicting Audrey's fifth day in detention, Audrey appears in sharp relief in the foreground. Curvaceous text swoops above her head and around her shoulder proclaiming, "we filled up all the rooms" (n.p.), yet the swathes of children in the rooms with Audrey appear as miniscule colorful dots, smaller than the buttons on her shirt. Instead of showing the reader the cramped quarters of the jail, the image looks festive as the spots of color representing other children are more akin to confetti than human forms.

The contradictions between the text and illustrations and the focus on Audrey's individual story reveal another trope common to CRM narratives: a focus on the actions of a few brave individuals (e.g., Parks and King) rather than collective action. Across the many pages dedicated to Audrey's time in jail, there is a vacillation between Audrey's feelings of loneliness and isolation and the author's description of increasing numbers of Birmingham youth filling the detention center. Ultimately, this book is a biographical account of Audrey Hendricks, but the event in which she participated was undoubtedly an extraordinary example of collective action. Yet, much like portrayals of King at the March on Washington, despite the clear significance of the Black community mobilizing against racist and discriminatory practices, the efforts of the collective are subsumed beneath the compelling story of an incredibly brave individual (Woodson, 2016).

\section{"Hot rolls, baptized in butter!"}

Amidst the fight for civil rights, another primary theme in the book is food. The first page of the book portrays Audrey's mother wearing an apron in the kitchen, holding a casserole dish next to heaping bowls of food. In the foreground, a smiling Audrey dons an apron and oven mitt as she clutches a pan of her favorite food: "hot rolls baptized in butter" (Levinson, 2017, n.p.). On the next page, everyone is seated and saying grace, arms linked around a table piled high with steaming platters of soul foods.

As the events around the Birmingham Children's Crusade begin, the focus on food fades quickly. However, once in jail, the detailed descriptions return as Audrey dines on "soupy, oily, tasteless, grits" (Levinson, 2017, n.p.). "She could barely spoon them into her mouth, let alone swallow them" (Levinson, 2017, n.p.). Levinson highlights the grits, alongside the uncomfortable cot, as evidence of 
Audrey's discomfort in jail. Indeed, after seven days in detention, Levinson describes how Audrey's "momma and daddy wrapped their arms tight around her, washed the jail off her, and for dinner... hot rolls, baptized in butter!" (n.p.). This final phrase is identical to that on the first page of the book, and has its own page dedicated to it in enlarged font. Unlike the other images throughout the book, the rolls in the scene after Audrey leaves jail are depicted realistically, presented by disembodied arms enrobed in a laurel wreath 10 for dramatic effect. The illustration makes clear that Audrey's victorious time in detention must be celebrated, and hot rolls are the ultimate reward.

The final page of the primary text takes place at Newberry's, the restaurant where Audrey initially wanted to sit inside to enjoy her ice cream. Audrey sits happily next to her father, licking "her spoon clean... like everybody else" (Levinson, 2017, n.p.). Thus, the book begins and ends with vivid language about food, albeit in two distinct settings (home vs. recently desegregated public). Like many nonfiction books, The Youngest Marcher includes an author's note and timeline for additional historical context. On the page that follows is a recipe for "hot rolls baptized in butter" (Levinson, 2017, n.p.). Levinson explains,

Mrs. Hendricks never wrote down her recipe. So (her daughters) experimented with many recipes and decided that this one tastes just right. Although I never tasted their mother's rolls, I make these for my family, and we agree that they taste just right! (n.p.)

Levinson, a white woman, feels the need to give the Hendricks sisters' recipe her stamp of approval. Moreover, the recipe is detached from the historical themes in the text, returning the book's focus to food rather than justice. In particular, given the book's celebratory mood in scenes including the rolls, ending the text with the recipe for a food equated with victory suggests the resolution of racial injustice. This peritextual feature contrasts sharply with the timeline on the previous page, which includes the bombing of the 16th Street Baptist Church in which four little Black girls were murdered by members of the KKK. As adult readers, we experienced great dissonance reading about this horrific event only to turn the page and discover a recipe. While the inclusion of recipes occasionally occurs in historical children's literature 11 , in the case of The Youngest Marcher, this specific recipe digresses from the primary theme of civic action found in the book and instead centers food as the theme deserving remembrance.

\section{Discussion}

Bell (1980) noted that "to suggest that what blacks really sought was the right to associate with whites, is to believe in a world that does not exist now and could not possibly have existed then" (p. 522); such historical depictions of the CRM, regardless of audience, are inarguably false. The CRM is an ideal moment in American history in which young children can engage with struggles toward injustice, yet such opportunities are often missed in favor of superficial tales like The Youngest Marcher that instead perpetuate problematic tropes of constant progress in U.S. society and racism as resolved. In this section, we describe how 
critical race media literacy can be utilized with The Youngest Marcher (Levinson, 2017) and similar popular media to present a more accurate counterstory of the CRM.

Critical race media literacy supports students in recognizing "the problematic ways people of color are represented in various media outlets while questioning the intentions behind such representations and working toward creating more-just representations in the media" (Hawkman \& Van Horn, 2019, p. 119). Such a perspective allows readers to understand that the uplifting narrative of individual youth agency found in The Youngest Marcher is far from extraordinary. Instead, Levinson's story falls neatly alongside the stories of individual exceptionalism for the greater American good ascribed to King and Parks (Woodson, 2016). Youth exemplars remain common in contemporary media, and students can critically consider how and why particular narratives have been highlighted, by and for whom; discuss how narratives have been received differently across a range of audiences; and assess the role of the media in determining whose stories are (un)told.

Such initial inquiries can and should lead to at least four CRM counterstories. First, young learners must understand the structural nature of racism rather than relegating it to individual acts. Such understanding should necessarily include attention to the dehumanizing conditions created by institutionalized racism, ensuring that the CRM is, as Ella Baker (1960) described, about "much bigger than a hamburger." Second, critical race media literacy skills can foster an understanding of the past and present struggle for Black critical patriotism. Third, when utilizing children's literature and other media, primary sources offer important counterstories that can nuance, complicate, or even contradict popular narratives (Salinas et al., 2012). Fourth, a critical race media literacy analysis considers the representations depicted by media creators as well as how different audiences may differently receive media.

First, due to the structural nature of racism, the struggle for freedom (for Black Americans as well as Native Americans, Asian Americans, Latinx, LGBTQ, religious minorities, and others) continues. Yet rather than delve into the complexities of power and dehumanization, educators of young children often prefer to conclude lessons on the CRM and other examples of historical injustice with happy endings in which oppression has been solved (Kellogg, 2019). Educators' insistence on happy endings and uncomplicated resolutions to social issues that are often presented in elementary school curriculum denies the ongoing inequities and injustices that persist worldwide. Swalwell and Payne (2019) argue that "we cannot pretend in our lessons to young people that institutions, policies, and practices in our civic life are healthy, fair, or just. Quite simply, they are not, and we should not teach children as if they are" (p. 128).

Second, Black critical patriotism reminds us that this country's founding ideals were never meant for Black persons (Busey \& Walker, 2017). During the CRM, Black Americans were fighting for personhood, the recognition of Black humanity, and that fight continues in the present day. Teachers can use historic examples like the Black Panther Party as well as more recent examples such as 
the Black Lives Matter Movement to teach students about Black critical patriotism and that the struggle continues. Children must be taught to understand disparities and inequities as outcomes of both individuals' choices and systems, and these lessons should be taught to both those who benefit from these systems and those who are marginalized by them (Swalwell \& Payne, 2019).

Third, books like The Youngest Marcher sanitize the historical narrative and subsequently downplay racial violence. While Audrey was in detention, one scene depicted girls marching despite being hosed down by firemen. This illustration shows the girls holding hands, water plunging far above them as they move, and contrasts sharply against primary sources of this event, which depict the ferocity with which the high-pressure hoses literally blew children away. Primary sources of Commissioner Bull Connor directing police to subdue youth activists with clubs and attack dogs paint a clearer picture of the cruel violence deliberately enacted upon the children of Birmingham. Therefore, primary sources should be featured alongside picturebooks to offer students more nuanced representations.

Lastly, a critical race media literacy lens demands an interrogation of who is telling the story of the CRM and for what audience. Educators of young children do not always consider the importance of author positionality, as evidenced by the continued presence of verifiably racist authors like Dr. Seuss in elementary classrooms (Ishizuka \& Stephens, 2019), and may in fact prefer narratives that avoid uncomfortable conversations related to racism and discrimination. However, as detailed above, such approaches are often in service of the protection of white children and deny the lived realities of Communities of Color. By analyzing authorship and considering race-conscious approaches to book selection as exemplified by Zapata et al. (2018), youth can become increasingly adept at interpreting content in and outside of school by considering the perspectives of the creators and the consumers.

\section{Conclusion}

Literacy scholar Rudine Sims Bishop (1992) stated, "The choice of books to be read and discussed in the nation's schools is of paramount importance" ( $p$. 40). We concur with Bishop, as the findings of our critical content analysis reveal that diverse children's literature, and even award-winning picturebooks that purportedly highlight civil rights activists, may contain deeply problematic depictions that erase important facts about the Black freedom struggle and the racial injustices that challenge our country today. As children develop racial biases before they enter the classroom (Winkler, 2009), teachers and families can and should engage in topics related to race and equity with young learners. It is our hope that picturebooks, if read with an emphasis on critical race media literacy, can support the development of such early educational inroads in the ongoing struggle toward justice for all. 


\section{Notes}

1. We capitalize the word Black in recognition of its political and social meaning as a liberating term (see Gotanda, 1991) while intentionally leaving white in lowercase to disrupt notions of racial domination.

2. Prior to the 1963 March on Washington, Gallup found that only $23 \%$ of Americans had favorable opinions of the demonstration. Data are from the Roper Center for Public Research, quoted in Elahe Izadi, "Black Lives Matter and America's Long History of Resisting Civil Rights Protest," Washington Post, April 19, 2016.

3. Ruby Bridges was a young Black girl who was one of the first children to desegregate New Orleans public schools.

4. Legal scholar Derrick Bell (1991) put forth a philosophy known as "racial realism" that acknowledges the permanence of white supremacy and the subordinate status of African Americans. He argues that acknowledging this reality helps us avoid despair and frees us to imagine the possibilities that can lead to fulfillment and triumph. Therefore, Bell (1992) argues that we need to "get real about our racial realism" (p. 5) and act.

5. Baker, E.J. (1969). "The Black Woman in the Civil Rights Struggle." Accessed September 19, 2019 from Milestone Documents: https://www.milestonedocuments.com/documents/view/ella-bakers-the-blackwoman-in-the-civil-rights-struggle/text

6. Historian Jacquelyn Dowd Hall (2005) argued that we must lengthen the time period that we typically associate with the Civil Rights Movement (1950s-1960s) as well as the geographic location (include the entire country) to represent the long history of African Americans fighting for civil rights. Importantly, the long civil rights movement is a recognition that African Americans have fought for civil rights since they were brought to this country against their will in 1619.

7. The Birmingham Children's Crusade took place on May 2, 1963, when thousands of Black children left school to gather at the 16th Street Baptist Church to participate in a non-violent march in support of civil rights. Police Commissioner Bull Connor ordered the children's arrest, and they were carried off to jail in school buses and paddy wagons. During the protest, police officers violently tried to halt the protest using clubs, fire hoses, and dogs, but the children continued singing and marching. It was later reported that this event convinced President John F. Kennedy to seek passage of the 1964 Civil Rights Act.

8. James Baldwin recognized that integrated lunch counters were not the primary goal of the Civil Rights Movement. In his appearance on the Dick Cavett show in 1968, four years after the passage of the Civil Rights Act and three years after the Voting Rights Act, a white philosophy professor asked him, "So why must we always concentrate on color?" The quote included was Baldwin's response to the philosophy professor.

9. According to Nettles (2007) "Soul food has its origin in the rural South and it was the diet of Blacks during the period of slavery.... The soul food diet is heavy on pork 
and cooked vegetables. It relies on the so-called lowly parts of the animal, those meat items rejected from the tables of slave owners and masters. And the vegetable items are illustrative of the slaves' inbred African tradition of 'living off the land'....Slavery and the rise of the Grand Plantation life in the seventeenth century created the soul food menu which survives to this day" (p. 112).

10. Since Ancient Greece, laurel wreaths have been considered a symbol of triumph.

11. For example, Pies from Nowhere: How Georgia Gilmore Sustained the Montgomery Bus Boycott by Dee Romito and illustrated by Laura Freeman and $A$ Birthday Cake for George Washington by Ramin Ganeshram and illustrated by Vanessa Brantley-Newton.

\section{References}

Anderson, C. (2016). White rage: The unspoken truth of our racial divide. Publishing USA.

Baker, E.J. (1960). "Bigger than a Hamburger". Retrieved from https://www.milestonedocuments.com/documents/view/ella-bakers-biggerthan-a-hamburger/text

Bell Jr., D. A. (1980). Brown v. Board of Education and the interest-convergence dilemma. Harvard Law Review, 518-533.

Bell, D. (1991). Racial realism. Connecticut Law Review, 24, 363-380.

Bell, D. (1992). Faces at the bottom of the well: The permanence of racism. Basic.

Bishop, R. S. (1992). Multicultural literature for children: Making informed choices. In V. J. Harris (Ed.), Teaching multicultural literature in grades K-8 (pp. 3753). Christopher-Gordon.

Blight, D. (2002). Race and reunion: The civil war in American memory. Belknap.

Bolgatz, J. (2007). More than Rosa Parks: Critical multicultural social studies in a fourth-grade class. Transformations: The Journal of Inclusive Scholarship and Pedagogy, 18(1), 39-51.

Botelho, M. J., \& Rudman, M. K. (2009). Critical multicultural analysis of children's literature: Mirrors, windows, and doors. Routledge.

Brown, A. L., \& Brown, K. D. (2010). Strange fruit indeed: Interrogating contemporary textbook representations of racial violence towards African Americans. Teachers College Record, 112(1), 31-67.

Brugar, K. A. (2015). Children as civic agents during the Civil Rights Movement. Social Studies and the Young Learner, 27(4), 5-10.

Brugar, K. A. (2018). The Carter G. Woodson Awards, 2018. Social Education, 82(3), 155-157. 
Buckingham, D. (2002). The making of citizens: Young people, news and politics. Routledge.

Busey, C. L., \& Walker, I. (2017). A dream and a bus: Black critical patriotism in elementary social studies standards. Theory \& Research in Social Education, 45(4), 456-488.

Cesaire A. (2000). Discourse on colonialism. Monthly Review Press.

Ciardiello, A. V. (2004). Democracy's young heroes: An instructional model of critical literacy practices. The Reading Teacher, 58(2), 138-147.

Cooperative Children's Book Center. (2019). Annual statistics on multicultural literature in publishing. Retrieved from https://ccbc.education.wisc.edu/ books/pcstats.asp

Dahlen, S. P. (2019). Picture this: The diversity in children's books 2018 infographic. Personal blog. Retrieved from https://readingspark. wordpress.com/2019/06/19/picture-this-diversity-in-childrens-books-2018infographic/

Delgado, R. (1989). Storytelling for oppositionists and others: A plea for narrative. Michigan Law Review, 87(8), 2411-2441.

Epstein, T. (2010). Interpreting national history: Race, identity, and pedagogy in classrooms and communities. Routledge.

Falkner, A. (2020). "Ain't gonna let nobody turn me around": Learning about race in the early grades. [Unpublished doctoral dissertation]. The University of Texas at Austin.

Ferreras-Stone, J., \& Demoiny, S. B. (2019). Why are people marching? Discussing justice-oriented citizenship using picture books. Social Studies and the Young Learner, 32(1), 3-9.

Gates, J. P., Ricks, P. H., \& Rodríguez-Astacio, R. M. (in press). Interrogating whiteness: A critical content analysis of Notable Picture Books recommended by the National Council for the Social Studies. In A. Hawkman \& S. Shear (Eds.), Marking the "invisible": Articulating whiteness in social studies education (pp. 139-168). Information Age.

Gay. R. (2015, June 23). Why I can't forgive Dylan Roof. The New York Times. Retrieved from https://www.nytimes.com/2015/06/24/opinion/why-i-cantforgive-dylann-roof.html.

Gotanda, N. (1991). A critique of "Our constitution is color-blind." Stanford Law Review, 44(1), 1-68.

Dowd Hall, J. (2005). The long civil rights movement and the political uses of the past. The Journal of American History, 91(4), 1233-1263.

Hawkman, A.M., \& Shear, S.B. (2017). "They're gonna sing the songs anyway": Thinking and teaching with theory and Disney music for social studies. In 
W.B. Russell, III, \& S. Waters (Eds.), Cinematic social studies: A resource for teaching and learning social studies with film (pp. 55- 78). Information Age Press.

Hawkman, A. M., \& Van Horn, S. E. (2019). What does it mean to be patriotic?: Policing patriotism in sports and social studies education. The Social Studies, 110(3), 1-18.

Holt, T. (2010). Children of fire: A history of African Americans. Hill and Wang.

Ishizuka, K., \& Stephens, R. (2019). The cat is out of the bag: Orientalism, antiblackness and white supremacy. Research on Diversity in Youth Literature, 1(2), 1-50.

Kellner, D., \& Share, J. (2005). Toward critical media literacy: Core concepts, debates, organizations, and policy. Discourse: Studies in the Cultural Politics of Education, 26(3), 369-386.

Kellogg, M. (2019). The struggle continues: How the endings of children's literature create false narratives of social movements. Teaching for Change. https://socialjusticebooks.org/the-struggle-continues/

Kent, S. (1999). Saints or sinners? The case for an honest portrayal of historical figures. Social Education, 68(1), 8-12.

Kohl, H. (1991). The politics of children's literature: The story of Rosa Parks and the Montgomery bus boycott. Journal of Education, 173(1), 35-50.

Kotler, J.A, Haider, T.Z. \& Levine, M.H. (2019). Identity matters: Parents' and educators' perceptions of children's social identity development. Sesame Workshop.

Ladson-Billings, G., \& Tate, W. F. (1995). Toward a critical race theory of education. Teachers College Record, 97(1), 47-62.

Levinson, C. (2017). The youngest marcher: The story of Audrey Faye Hendricks, a young civil rights activist. Atheneum Books for Young Readers.

Libresco, A. S. (2018). And the children shall lead: Using the 2018 Notable Books to nurture young citizen-activists. Social Education, 82(3), 158-162.

Lindquist, J. (2019). Teaching the Civil Rights Movement through the eyes of young participants. Social Studies and the Young Learner, 32(1), 20-25.

Love, B. L. (2019). We want to do more than survive: Abolitionist teaching and the pursuit of educational freedom. Beacon Press.

Meiners, E. R. (2015). Trouble with the child in the carceral state. Social Justice, 41 (3 (137), 120-144.

Mitra, D., \& Serriere, S. C. (2015). Civic education in the elementary grades: Promoting student engagement in an era of accountability. Teachers College Press.

Morgan, H. (2009). Picture book biographies for young children: A way to teach multiple perspectives. Early Childhood Education Journal, 37(3), 219-227. 
Myers, C. (2014, March 15). The apartheid of children's literature. New York Times. Retrieved from https://www.nytimes.com/2014/03/16/ opinion/sunday/the-apartheid-of-childrens-literature.html

Myers, W.D. (2014, March 15). Where are the people of color in children's books? New York Times. Retrieved from https://www.nytimes.com/2014/ 03/16/opinion/sunday/where-are-the-people-of-color-in-childrensbooks.html

Nettles, K. D. (2007). "Saving” soul food. Gastronomica, 7(3), 106-113.

Packnett, B. (2019, October 2). The real reason Amber Guyger was convicted. Vox. Retrieved from https://www.vox.com/first-person/2019/10/2/ 20895198/amber-guyger-botham-jean-verdict

Peck, R. (Director). (2016). I am not your Negro [Motion Picture]. United States: Velvet Film.

Pierce, C. (1970). Offensive mechanisms. In F. B. Barbour (Ed.), The Black seventies (pp. 265-282). Porter Sargent.

Ramirez, P. C., \& Jaffee, A. T. (2016). Culturally responsive active citizenship education for newcomer students: A cross-state case study of two teachers in Arizona and New York. International Journal of Multicultural Education, 18(1), 45-67.

Rodríguez, N. N. (2018). From margins to center: Developing cultural citizenship education through the teaching of Asian American history. Theory \& Research in Social Education, 46(4), 528-573.

Rodríguez, N. N., \& Kim, E. J. (2018). In search of mirrors: An Asian Critical Race Theory content analysis of Asian American picturebooks from 2007-2017. Journal of Children's Literature, 44(2), 16-33.

Rodríguez, N. N., \& Salinas, C. S. (2019). "La lucha todavía no ha terminado/The struggle is not yet over: Teaching immigration through testimonio and difficult funds of knowledge. Journal of Curriculum Theorizing, 34(3), 136149.

Salinas, C., \& Castro, A. (2010). Disrupting the official curriculum: Cultural biography and the curriculum decision making of Latino preservice teachers. Theory and Research in Social Education, 38(3), 428-46.

Salinas, C., Blevins, B., \& Sullivan, C. (2012). Critical historical thinking: When official narratives collide with other narratives. Multicultural Perspectives, 14(1), 18-27.

Short, K. (2017). Critical content analysis as a research methodology. In H. Johnson, J. Mathis, \& K. Short (Eds.), Critical content analysis of children's and young adult literature (pp. 1-15). Routledge.

Sipe, L. R. (2001). Picturebooks as aesthetic objects. Literacy, Teaching and Learning, 6(1), 23-42. 
Smith, J. (2019, August 12). It isn't much to ask that cops have a higher standard for killing people. Rolling Stone. Retrieved from https://www.rollingstone. $\mathrm{com} /$ politics/politics-news/it-isnt-much-to-ask-that-cops-have-a-higherstandard-for-killing-people-870616/.

Solórzano, D. G., \& Yosso, T. J. (2002). Critical race methodology: Counterstorytelling as an analytical framework for education research. Qualitative Inquiry, 8(1), 23-44.

Swalwell, K., \& Payne, K. A. (2019). Critical civic education for young children. Multicultural Perspectives, 21(2), 127-132.

Theoharis, J. (2018). A more beautiful and terrible history: The uses and misuses of civil rights history. Boston, MA: Beacon Press.

Thomas, E. E., Reese, D., \& Horning, K. T. (2016). Much ado about A Fine Dessert: The cultural politics of representing slavery in children's literature. Journal of Children's Literature, 42(2), 6-17.

Vickery, A.E. (2016). "I know what you are about to enter": Lived experiences of African American women as the curricular foundation for teaching citizenship. Gender and Education, 28(6), 725-741.

Vickery, A.E. (2017). "You excluded us for so long and now you want us to be patriotic?" African American women teachers contemplating the quandary of citizenship. Theory and Research in Social Education, 45(3), 318-348.

Winkler, E. N. (2009). Children are not colorblind: How young children learn race. PACE: Practical Approaches for Continuing Education, 3(3), 1-8.

Woodson, A. N. (2016). We're just ordinary people: Messianic master narratives and Black youths' civic agency. Theory \& Research in Social Education, 44, 184-211.

Woodson, J. (2003). Who can tell my story? In D. L. Fox \& K. G. Short (Eds.), Stories matter: The complexity of cultural authenticity in children's literature (pp. 41-45). National Council of Teachers of English.

Wills, J. (2001). Missing in interaction: Diversity, narrative, and critical multicultural social studies. Theory and Research in Social Education, 29(1), 43-64.

Wills, J. S. (2005). 'Some people even died': Martin Luther King, Jr, the civil rights movement and the politics of remembrance in elementary classrooms. International Journal of Qualitative Studies in Education, 18(1), 109-131.

Yorio, K. (2018, October 24). \#OwnVoices not familiar to all. School Library Journal. Retrieved from https://www.slj.com/?detailStory=ownvoices-notfamiliar-all.

Yosso, T. J. (2002a) Critical race media literacy: Challenging deficit discourse about Chicanas/os. Journal of Popular Film and Television, 30(1), 52-62.

Yosso, T. J. (2002b). Toward a critical race curriculum. Equity \& Excellence in Education, 35(2), 93-107. 
Zapata, A., King, C., King, L., \& Kleekamp, M. (2019). Thinking with raceconscious perspectives: Critically selecting children's picture books depicting slavery. Multicultural Perspectives, 21(1), 25-32.

\section{Author Contact}

Noreen Naseem Rodríguez, nrdz@iastate.edu

School of Education, 901 Stange Road, 1720C Lagomarcino Hall, Ames, IA 50011

Amanda E. Vickery, Amanda.Vickery@unt.edu

College of Education, 1155 Union Circle \#310740, Matthews Hall 204B, Denton, TX 76203 